\title{
Vigna marina (Fabaceae) - A new addition to the flora of West Bengal
}

\author{
Bandana Bhattacharjee $^{1}$, Avishek Bhattacharjee ${ }^{1}$, Kaliyamurthy Karthigeyan ${ }^{1 *}$, Ajanta Dey $^{2}$ \\ ${ }^{I}$ Central National Herbarium, Botanical Survey of India, A.J.C.B. I ndian Botanic Garden, Howrah - 711 103, \\ West Bengal, India \\ ${ }^{2}$ Nature Environment and Wildlife Society (NEWS), 10, Chowringhee Terrace, Kolkata-700 020, West Bengal, India. \\ *Corresponding Author: Kaliyamurthy Karthigeyan, Central National Herbarium, Botanical Survey of \\ India, A.J.C.B. Indian Botanic Garden, Howrah - 711 103, West Bengal, India.
}

Abstract: Vigna marina (Burm.) Merr. (Fabaceae) is reported for the first time from 'Buraburir Tot' of Sundarbans, West Bengal constituting a new record forthe state.

Keywords: 'Buraburir Tot', Ceratotropis, Mangrove, Sundarbans.

\section{INTRODUCTION}

The genus Vigna Savi (Fabaceae) is represented by 104 species (Lewis \& al., 2005) in the world and 23 to 25 species[under subgenus Ceratotropis (Piper) Verdc., commonly known as Asian Vigna] in India (Babu et al., 1987; Sanjappa, 1992; Aitawade et al., 2012). In West Bengal, 9 species of the genus have been reported, viz. V. aconitifolia (Jacq.) Marechal, V. adenantha (G. Mey.) Marechal \& al., V. clarkei Prain, V. luteola (Jacq.) Benth., V. pilosa (Klein ex Willd.) Baker, V. radiata var. setulosa (Dalzell) Ohwi \& Ohashi, V. trilobata (L.) Verdc., V. umbellata (Thunb.) Ohwi \& H. Ohashi and V. vexillata (L.) A. Rich. (Bandyopadhyay, 2015).

During field surveys in connection with the project "Evaluation Support for Mangrove Plantation in Sundarbans, South 24 Parganas, West Bengal" in March 2018 and January 2019, some plants belonging to the genus Vigna were found on the sand dunes of 'Buraburir Tot' of Gobardhanpur village, Patharpratima Block of South 24 Parganas district, West Bengal. After study of the collected specimens, the species has been identified as Vigna marina (Burm.) Merr., a species which is not being reported from West Bengal before. A detailed description and a photo-plate (Fig.1) have been provided to aid in identification of the species.

\section{TAXONOMIC ACCOUNT}

Vigna marina (Burm.) Merr., Interpr. Herb. Amboin.: 285. 1917; Babu et al., Bull. Bot. Surv. India. 27: 17. 1987; Sanjappa, Leg. India: 274. 1992. Phaseolus marinus Burm. Ind. Alter Univ. Amb.: 18. 1769. Dolichos luteus Sw., Prodr.: 105. 1788. Vigna lutea (Sw.) A. Gray, U.S. Expl. Exped., Phan. 15: 452. 1854; Baker in Hook. f., Fl. Brit. India 2: 205. 1876.

Perennial herbs, trailing. Stems slender, up to several meters, covered with setose hairs, turning glabrescent on older stems. Stipules 2-lobed at base, ovate, 3-5 mm. Leaves 3-foliolate, $5-11 \mathrm{~cm}$ long; petioles 2-5(-7) cm long, densely covered with setose hairs; leaflets ovate-orbicular to obovate, $2.5-5(-9.5) \times 1.5-4(-7.5) \mathrm{cm}$, entire, sparsely setose on both surfaces, especially on the veins, base broadly cuneate, obtuse at apex, minutely emarginate. Racemes axillary, $2-4 \mathrm{~cm}$; peduncles $3-13 \mathrm{~cm}$. Calyx 3-4 mm long; teeth deltoid, 1.5-2 mm long, upper 2 connate. Corolla yellow; standard broadly obovate, $1.2-1.5 \times 1.4-2 \mathrm{~cm}$; wings $1.2-1.5 \times 0.6-0.8 \mathrm{~cm}$; keel $1-1.2 \times 0.5-0.6 \mathrm{~cm}$. Stamens 9+1, included; staminal tube c. $5 \mathrm{~mm}$ long; free filament $8-9 \mathrm{~mm}$ long; anther dorsifixed, yellow. Pistil 1.5$1.8 \mathrm{~cm}$ long; ovary linear to obclavate, $5-6 \times 0.6-0.8 \mathrm{~mm}$; style filiform, $1.1-1.3 \mathrm{~cm}$ long, curved from the middle, densely hairy before stigma, shortly beaked beyond stigma. Pods linear-oblong, 3-6 $\times 0.5-0.8 \mathrm{~cm}$, sparsely pubescent when young, glabrous at maturity, slightly constricted between seeds. Seeds 4-7, yellowish-brown, oblong, 5-7 × 4.5-5 mm. 


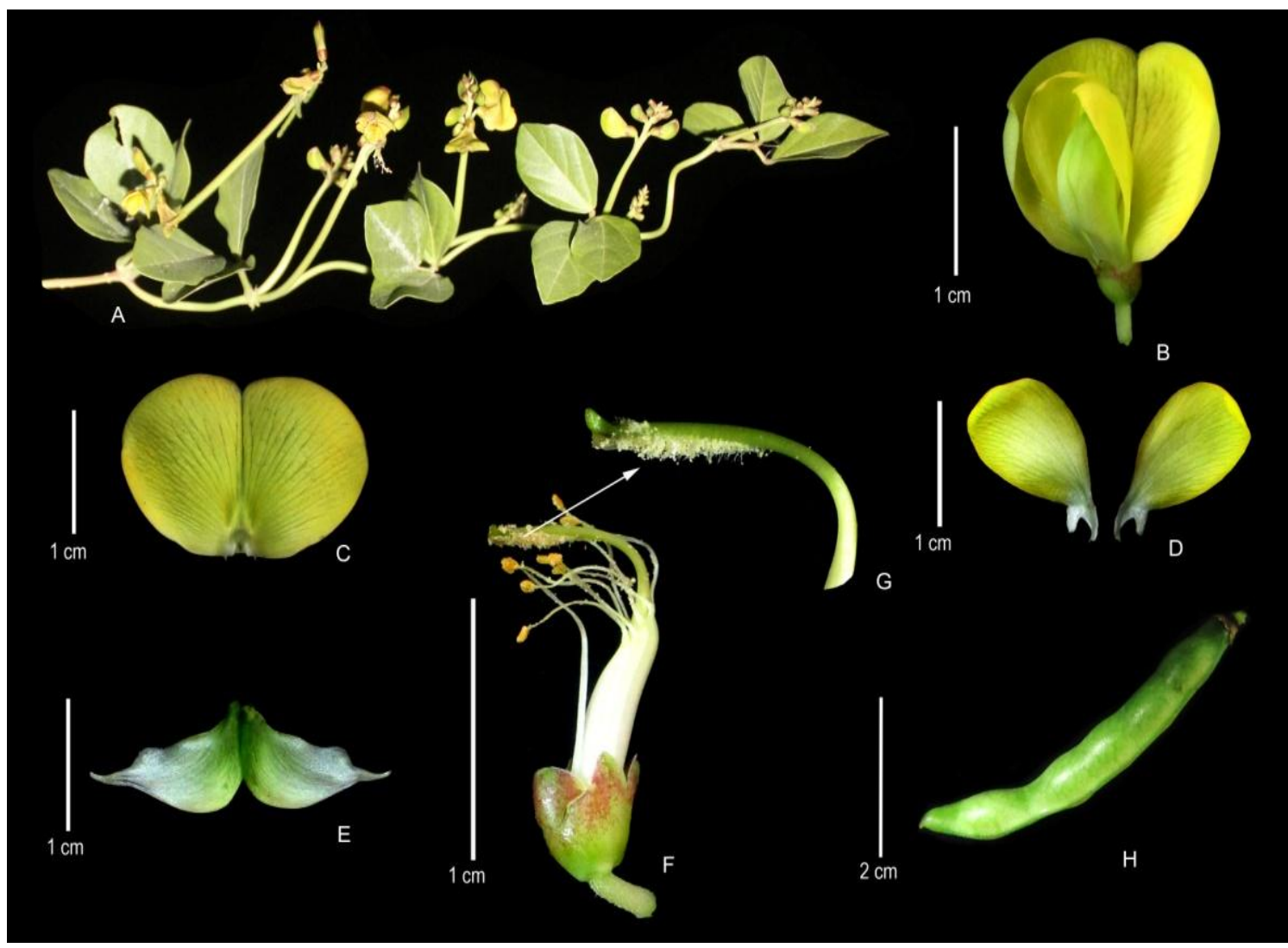

Figure1. Vigna marina (Burm.) Merr.: A. Flowering twig; B. Flower; C. Standard petal; D. Wings; E. Keels; F. Calyx, androecium and gynoecium; G. Portion of style with hairy apical part; H. Pod. (K. Karthigeyan \& B. Bhattacharjee 65107, CAL)

Flowering \& Fruiting: December-March

Distribution: INDIA [Andaman and Nicobar Islands, Kerala, West Bengal (reported here)]; widely found in tropical beaches around the world in Asia, Africa, North America, Central America and Caribbean, South America, Europe and Oceania (CABI, 2019).

Voucher specimens: INDIA: West Bengal: South 24 Parganas district, Patharpratima Block, Gobardhanpur village, on sand dune of 'Buraburir Tot', 29.03.2018, K. Karthigeyan \& B. Bhattacharjee 65104 (CAL; CAL0000027324, CAL0000027325, CAL0000027326); 'Buraburir Tot', 11.01.19, K. Karthigeyan \& B. Bhattacharjee 65107 (CAL; CAL0000027327).

3. CONCLUSION

Based on the recent collections, it is found that Vigna marina, a mangrove associate, hitherto unknown for the flora of West Bengal, India, is reported for the first time constituting a new report to the flora of the state.

\section{ACKNOWLEDGEMENTS}

We are thankful to the Director, Botanical Survey of India (BSI), Kolkata and Head of Office, Central National Herbarium, BSI, Howrah for providing research facilities and Udo Censkowsky (bluesensus), along with ALDI SÜD, for providing financial support to the 'Nature Environment and Wildlife Society (NEWS)' in afforestation of mangroves in the two localities of Sundarbans. We are also thankful to Mr. Paritosh Giri, Mr. Keshab Kumar Ghosh, Mr. Saurav Bera and other staff of NEWS for their help during field surveys.

\section{REFERENCES}

[1] Aitawade M.M., Sutar S.P., Rao S.R., Malik S.K., Yadav S.R. and Bhat K.V. (2012). Section Ceratotropis of subgenus Ceratotropis of Vigna (Leguminosae-Papilionoideae) in India with a new species from Northern Western Ghats. Rheedea 22(1), 20-27.

[2] Babu C.R., Subodh K.S. and Johri B.M. (1987). Leguminosae-Papilionoideae: Tribe - Phaseoleae. Bull. Bot. Surv. India 27, 1-28. 
[3] Bandyopadhyay, S. (2015). Phaseolinae. In: Paul T.K., Lakshminarasimhan P., Chowdhery H.J., Dash S.S. and Singh, P. Flora of West Bengal, vol. 2 (Leguminosae - Aizoaceae). Botanical Survey of India, Kolkata. pp. 170-176.

[4] CABI (2019). Invasive Species Compendium. Wallingford, UK: CAB International. www.cabi.org/isc. Accessed [10.05.2019]

[5] Lewis G.P., Schrine B., Mackinder B. and Lock J.M. (2005). Legumes of the World. Royal Botanic Gardens, Kew.

[6] Sanjappa, M. (1992). Legumes of India. Bishen Singh Mahindra Pal Singh, Dehra Dun.

Citation: Kaliyamurthy Karthigeyan, et.al.,"Vigna marina (Fabaceae) - A new addition to the flora of West Bengal”. International Journal of Advanced Research in Botany (IJARB), vol. 5, no. 2, pp. 45-47, 2019. http://dx.doi.org/10.20431/2455-4316.0502005.

Copyright: (C) 2019 Authors. This is an open-access article distributed under the terms of the Creative Commons Attribution License, which permits unrestricted use, distribution, and reproduction in any medium, provided the original author and source are credited. 